\title{
FISH SPECIES CAUGHT BY SHRIMP TRAWLERS OFF THE COAST OF SERGIPE, IN NORTH-EASTERN BRAZIL, AND THEIR LENGTH-WEIGHT RELATIONS
}

\author{
Thaíza M.R.R. BARRETO ${ }^{1}$, Kátia M.F. FREIRE ${ }^{1 *}$, Josafá J.C. REIS-JÚNIOR ${ }^{1}$, Leonardo C. \\ ROSA $^{2}$, Alfredo CARVALHO-FILHO ${ }^{3}$, and Matheus M. ROTUNDO ${ }^{4}$ \\ ${ }^{1}$ Fishing Ecology Laboratory (LEP), Department of Fisheries Engineering and Aquaculture (DEPAQ), Federal Uni- \\ versity of Sergipe (UFS), São Cristóvão, Sergipe, Brazil \\ ${ }^{2}$ Benthic Ecology Laboratory (LEB/DEPAQ/UFS), São Cristóvão, Sergipe, Brazil \\ ${ }^{3}$ Fish Bizz Ltda, São Paulo, São Paulo, Brazil \\ ${ }^{4}$ Zoological Collection of Santa Cecília University (AZUSC/UNISANTA), Santos, São Paulo, Brazil
}

Barreto T.M.R.R., Freire K.M.F., Reis-Júnior J.J.C., Rosa L.C., Carvalho-Filho A., Rotundo M.M. 2018. Fish species caught by shrimp trawlers off the coast of Sergipe, in north-eastern Brazil, and their length-weight relations. Acta Ichthyol. Piscat. 48 (3): 277-283.

\begin{abstract}
The objective of this study was to report all fish species caught by shrimp trawlers based in Pirambu, in the state of Sergipe, Brazil and estimate the length-weight relation (LWR) for the most abundant species in the samples. Four samples were collected monthly from four shrimp trawlers. A total of 8522 fishes were caught (89 species; 38 families). LWRs were estimated for 18 species having the parameter $b$ within the range of 2.5-3.5: Cathorops spixii (Agassiz, 1829); Stellifer brasiliensis (Schultz, 1945); Pellona harroweri (Fowler, 1917); Odontognathus mucronatus Lacepède, 1800; Paralonchurus brasiliensis (Steindachner, 1875); Stellifer rastrifer (Jordan, 1889); Isopisthus parvipinnis (Cuvier, 1830); Selene brownii (Cuvier, 1816); Anchoa spinifer (Valenciennes, 1848); Trinectes paulistanus (Miranda Ribeiro, 1915); Symphurus plagusia (Bloch et Schneider, 1801); Chirocentrodon bleekerianus (Poey, 1867); Stellifer stellifer (Bloch, 1790); Citharichthys spilopterus Günther, 1862; Ctenosciaena gracilicirrhus (Metzelaar, 1919); Anchoviella lepidentostole (Fowler, 1911); Peprilus crenulatus Cuvier, 1829; Genyatremus cavifrons (Cuvier, 1830). Five new maximum size records were reported in this study for Trinectes paulistanus, Citharichthys spilopterus, Anchoviella lepidentostole, Chirocentrodon bleekerianus, and Stellifer brasiliensis. Fifty-four new maximum weight records were also registered. LWR estimated here are the first for Genyatremus cavifrons and Peprilus crenulatus.
\end{abstract}

Keywords: weight-length relation, shrimp trawlers, bycatch, discard, WLR

\section{INTRODUCTION}

Length-weight relations (LWR) are used to estimate the weight corresponding to a given length, which reflects different conditions for various populations throughout their life cycle (Wootton 1998, Freire et al. 2009). LWRs and their parameter $b$ are not considered interesting science for some fisheries scientists (Hilborn and Walters 1992, Froese 2006), even though these relations are important for estimating biomass where weighing fishes is not possible (Macieira and Joyeux 2009) or for species where such relations were not previously known (Froese 2006). Although LWRs have been estimated for many fish species along the Brazilian coast, data are still missing for many species, especially those that are not commercially important, or localities
(Freire et al. 2009). This paper aims to identify all fish species caught by shrimp trawlers off the coast of Sergipe and estimate LWRs for the most abundant species.

\section{MATERIAL AND METHODS}

Samples were collected from the artisanal shrimp trawl fishery based in the municipality of Pirambu, in the state of Sergipe (Fig. 1). Four samples were obtained monthly from March 2015 to May 2016, with the exception of April and December 2015 and April 2016 due to two closed seasons per year for the shrimp fishery (90 days in total). Each sample, with approximately $6 \mathrm{~kg}$, was separated immediately after the last trawl before heading to the port and was stored on ice and later kept frozen

\footnotetext{
" Correspondence: Dr Kátia M. F. Freire, Laboratório de Ecologia Pesqueira (LEP), Departamento de Engenharia de Pesca e Aquicultura (DEPAQ), Universidade Federal de Sergipe (UFS), Rodovia Marechal Rondon, S/N, Jardim Rosa Elze, São Cristóvão, Sergipe, $49100-000$ Brazil, phone: +55 7931947401 , e-mail: (KMFF)kmffreire2018@gmail.com, (TMRRB) barreto.thaiza@gmail.com, (JJCRJ) josafajunior13@hotmail.com, (LCR) leonardo.rosa@rocketmail.com, (ACF) alfie@telnet.com.br, (MMR)mmrotundo@unisanta.br.
} 


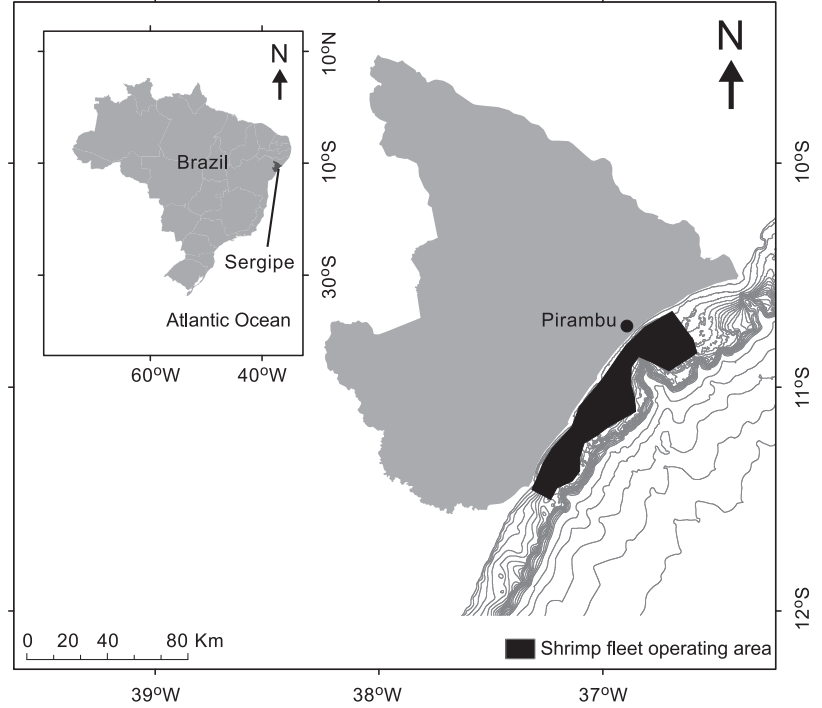

Fig. 1. The municipality of Pirambu, in the state of Sergipe, and the shrimp-fleet operating area

at the Laboratório de Ecologia Pesqueira da Universidade Federal de Sergipe (LEP/UFS) until further processing. All fish species collected here were identified and catalogued at LEP/UFS collection. Additional specimens were sent to the Acervo Zoológico da Universidade Santa Cecília (AZUSC/UNISANTA).

Total length (TL, cm) and total weight (TW, g) of each specimen were determined using an ichthyometer (precision: $1 \mathrm{~mm}$ ) and a digital scale (precision: $0.1 \mathrm{~g}$ ), respectively. Length-weight relations

$$
T W=\mathrm{a} \cdot T L^{\mathrm{b}}
$$

were estimated for all species with the sample size larger than 20 and with the maximum observed length corresponding to more than $70 \%$ of the maximum size reported in FishBase (Froese and Pauly 2018) or significantly higher than the length at first maturity $\left(L_{\mathrm{m}}\right)$. A linear regression was applied to the logarithm of both length and weight to estimate the parameters $a$ and $b$ and their respective confidence intervals were calculated. A $t$-test was used to determine if $b$ was statistically different from $3(\alpha=0.05)$.

The occurrence of the fish species reported in this study for the state of Sergipe was compared with existing information available in FishBase as well as their LWRs. FishBase is the largest online encyclopaedia of fishes and contains information on 34000 species (Froese and Pauly 2018), based on scientific publications, which has been increasingly cited in the scientific literature (Stergiou and Tsikliras 2006).

\section{RESULTS}

A total of 8522 fishes were caught, representing 89 species and 38 families (Table 1). The total weight of all samples was about $151.6 \mathrm{~kg}$ and the most representative families were Sciaenidae (35\% of the total weight caught), Ariidae (17\%), Pristigasteridae (10\%), and Haemulidae (7\%). The most abundant species in the samples were Cathorops spixii (Agassiz, 1829); Larimus breviceps Cuvier, 1830; Stellifer brasiliensis (Schultz, 1945); and Pellona harroweri (Fowler, 1917); representing about $15 \%, 11 \%, 8 \%$, and $7 \%$ of the total weight, respectively. Pellona harroweri was the main species considering number (1077) and was present in all samples, followed by L. breviceps (1075), C. spixii (1022), and S. brasiliensis (961). Eleven of these species are not reported in FishBase for the state of Sergipe: Aspistor quadriscutis (Valenciennes, 1840); Cyclopsetta chittendeni Bean, 1895; Cynoscion leiarchus (Cuvier, 1830); Cynoscion microlepidotus (Cuvier, 1830); Bathytoshia centroura (Mitchill, 1815); Diplectrum radiale (Quoy et Gaimard, 1824); Notarius grandicassis (Valenciennes, 1840); Ogcocephalus parvus Longley et Hildebrand, 1940; Raneya brasiliensis (Kaup, 1856); Stellifer brasiliensis (Schultz, 1945); and Stellifer stellifer (Bloch, 1790).

Five new maximum size records were established in this study in relation to the information currently available in FishBase (Froese and Pauly 2018): $18.2 \mathrm{~cm}$ for Trinectes paulistanus (Miranda Ribeiro, 1915), 21.0 $\mathrm{cm}$ for Citharichthys spilopterus Günther, 1862, $16.4 \mathrm{~cm}$ for Anchoviella lepidentostole (Fowler, 1911), $16.1 \mathrm{~cm}$ for Chirocentrodon bleekerianus (Poey, 1867), and 17.0 $\mathrm{cm}$ for Stellifer brasiliensis (Schultz, 1945) (all of them unsexed).

Parameters $a$ and $b$ of the LWR estimated for 18 fish species are summarized in Table 2, along with their standard errors. All regressions were statistically significant $(P<0.05)$. Parameter $a$ ranged from 0.00240 for Paralonchurus brasiliensis (Steindachner, 1875) to 0.03135 for Genyatremus cavifrons (Cuvier, 1830), and parameter $b$ ranged from 2.578 for $C$. bleekerianus to 3.424 for $P$. brasiliensis.

\section{DISCUSSION}

Freire and Araújo (2016) listed commercial fish species for the state of Sergipe. Thirty species are also listed here, indicating they are, in fact, commercially important. Juveniles of important species correspond to a high proportion of the bycatch of shrimp trawlers and species without market value are probably discarded or consumed by fishers (Tischer and Santos 2001, Branco 2005). Thus, a high proportion of the catch may not be accounted for in officially reported catch statistics. It is also worth pointing out that many species reported here were never registered in previous studies carried in the area related to the bycatch of shrimp trawlers in the state of Sergipe (Santos 1996, Decken unpublished", Anonymous unpublished $\left.{ }^{* *}\right)$.

\footnotetext{
* Decken K.V. 1986. O setor pesqueiro na economia do estado de Sergipe. [The fishing sector in the economics of the state of Sergipe.] Superintendência de Desenvolvimento da Pesca, SUDEPE, Aracaju-Sergipe. [In Portuguese.]

"** Anonymous. Perfil da pesca de camarão no estado de Sergipe, Brazil. [Profile of the shrimp fishery in the state of Sergipe.] Superintendência de Desenvolvimento da Pesca, SUDEPE, Aracaju-Sergipe. [In Portuguese.]
} 


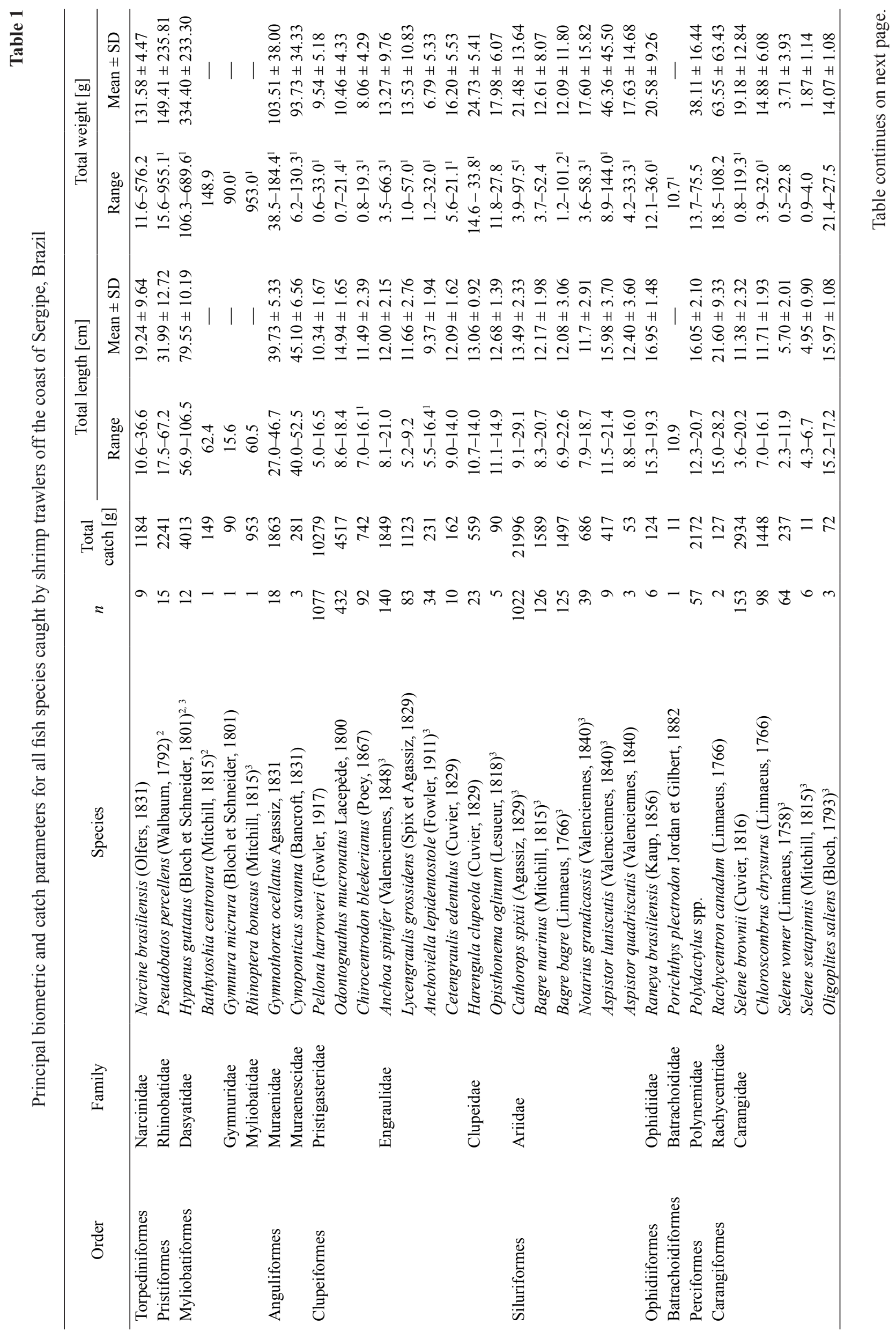




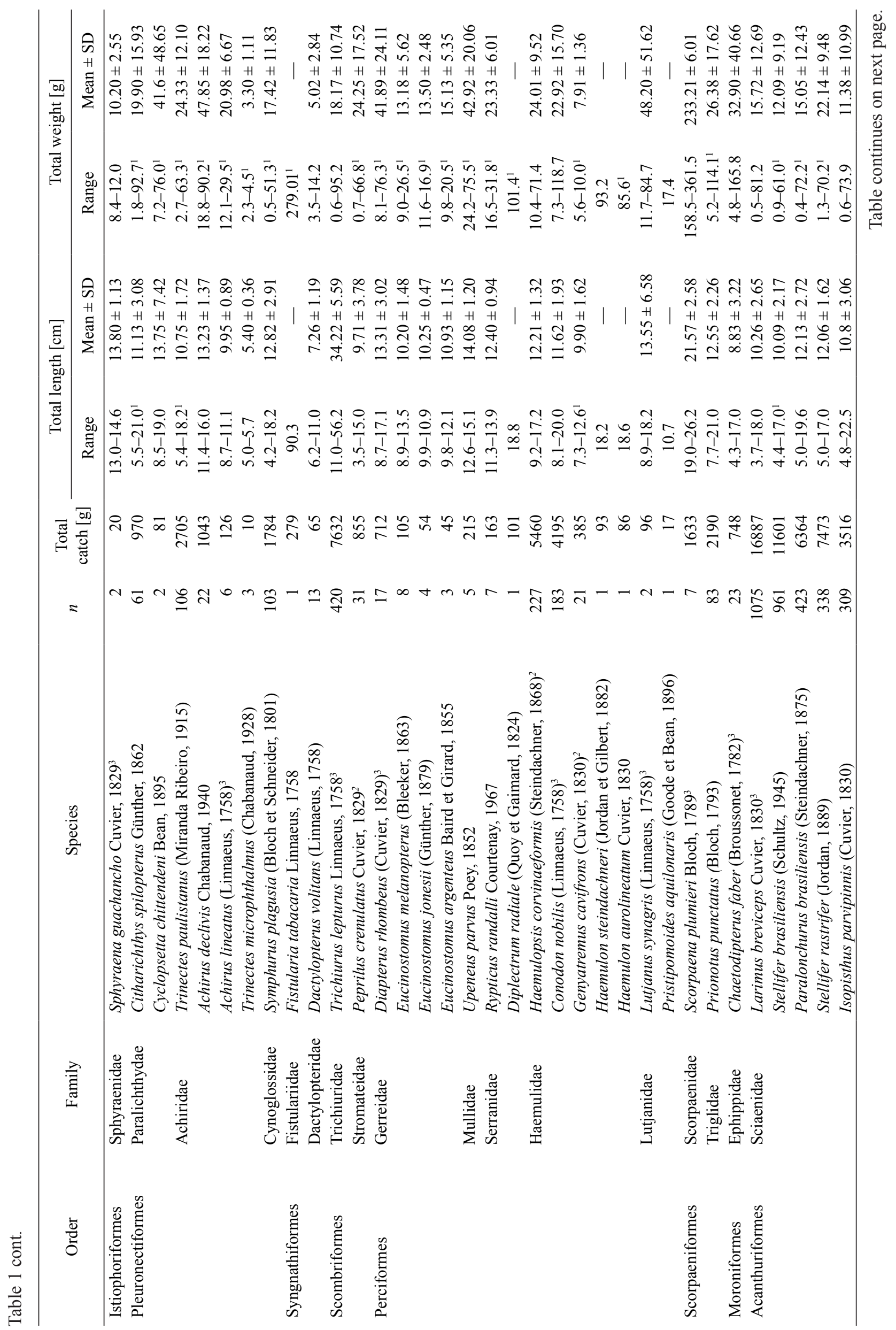




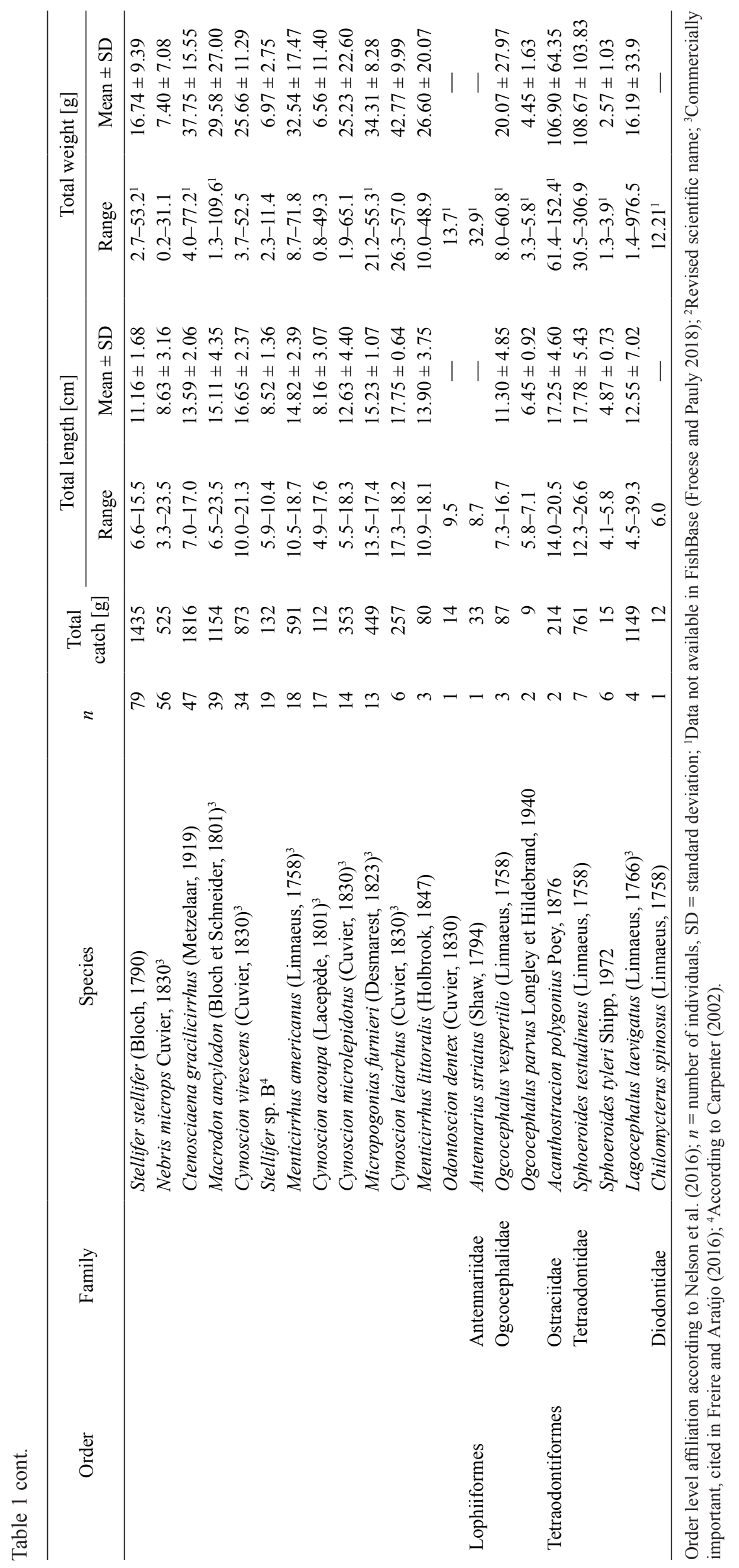


Table 2

Length-weight relations (LWRs) for all fish species caught by shrimp trawlers off the coast of Sergipe, Brazil (with $n$ $\geq 20$ )

\begin{tabular}{|c|c|c|c|c|c|c|c|c|c|}
\hline \multirow[b]{2}{*}{ Species } & \multirow[b]{2}{*}{$n$} & $\mathrm{TL}[\mathrm{cm}]$ & \multirow[b]{2}{*}{$\mathrm{TL}_{\max }$} & \multirow[b]{2}{*}{$L_{\mathrm{m}}$} & \multirow[b]{2}{*}{$a$} & \multirow[b]{2}{*}{ SE $\log _{10} a$} & \multirow[b]{2}{*}{$b$} & \multirow[b]{2}{*}{$\mathrm{SE} b$} & \multirow[b]{2}{*}{$r^{2}$} \\
\hline & & Range & & & & & & & \\
\hline Cathorops spixii & 922 & $9.1-29.1$ & 30.0 & - & 0.00501 & 0.07250 & $3.181^{5}$ & 0.028 & 0.981 \\
\hline Stellifer brasiliensis & 883 & $4.4-17.0^{4}$ & 14.5 & 7.3 & 0.00563 & 0.04333 & $3.257^{5}$ & 0.019 & 0.932 \\
\hline Pellona harroweri & 755 & $5.0-16.5$ & 18.0 & - & 0.00952 & 0.06468 & 2.969 & 0.028 & 0.971 \\
\hline Odontognathus mucronatus & 428 & $8.6-18.4$ & 19.2 & - & 0.00277 & 0.07587 & $3.248^{5}$ & 0.030 & 0.964 \\
\hline Paralonchurus brasiliensis & 400 & $5.0-19.6$ & 30.0 & 15.7 & 0.00240 & 0.08994 & $3.424^{5}$ & 0.036 & 0.923 \\
\hline Stellifer rastrifer & 322 & $5.0-17.0$ & 32.1 & 9.8 & 0.00756 & 0.09541 & $3.182^{5}$ & 0.038 & 0.977 \\
\hline Isopisthus parvipinnis & 302 & $4.8-22.5$ & 25.0 & 15.9 & 0.00630 & 0.07832 & 3.078 & 0.033 & 0.955 \\
\hline Selene brownii ${ }^{1}$ & 149 & $3.6-20.2$ & 29.0 & - & 0.01754 & 0.10391 & $2.833^{5}$ & 0.043 & 0.955 \\
\hline Anchoa spinifer & 128 & $8.1-21.0$ & 24.0 & - & 0.00386 & 0.14540 & $3.222^{5}$ & 0.059 & 0.967 \\
\hline Trinectes paulistanus & 104 & $5.4-18.2^{4}$ & 18.0 & - & 0.01824 & 0.25548 & 3.009 & 0.108 & 0.959 \\
\hline Symphurus plagusia & 101 & $4.2-18.2$ & 25.0 & - & 0.00389 & 0.12819 & $3.225^{5}$ & 0.051 & 0.882 \\
\hline Chirocentrodon bleekerianus $^{2}$ & 89 & $7.0-16.1^{4}$ & 11.2 & 7.6 & 0.01324 & 0.28281 & $2.578^{5}$ & 0.116 & 0.963 \\
\hline Stellifer stellifer & 68 & $6.6-15.5$ & 21.0 & 7.5 & 0.00552 & 0.22621 & $3.287^{5}$ & 0.094 & 0.884 \\
\hline Citharichthys spilopterus & 59 & $5.5-21.0^{4}$ & 20.0 & - & 0.01522 & 0.21824 & $2.799^{5}$ & 0.091 & 0.852 \\
\hline Ctenosciaena gracilicirrhus $^{2}$ & 45 & $7.0-17.0$ & 21.0 & - & 0.00631 & 0.16291 & $3.302^{5}$ & 0.063 & 0.960 \\
\hline Anchoviella lepidentostole & 28 & $5.5-16.4^{4}$ & 13.1 & - & 0.00474 & 0.32489 & 3.181 & 0.146 & 0.941 \\
\hline Peprilus crenulatus $^{3}$ & 27 & $3.5-15.0$ & - & - & 0.01836 & 0.12115 & 2.979 & 0.054 & 0.992 \\
\hline Genyatremus cavifrons $^{3}$ & 21 & $7.3-12.6$ & - & - & 0.03135 & 0.29881 & 2.751 & 0.131 & 0.959 \\
\hline
\end{tabular}

$n=$ number of individuals, $\mathrm{TL}=$ total length observed, $\mathrm{TL}_{\max }=$ total length reported in FishBase, $L_{\mathrm{m}}=$ length at first maturity reported in FishBase; $a$ and $b=$ parameters of the LWR, $\mathrm{SE}=$ standard error, $r^{2}=$ coefficient of determination; only species with more than 20 specimens examined and the maximum observed length representing more than $70 \%$ of the maximum size reported in FishBase (Froese and Pauly 2018) or significantly higher than $L_{\mathrm{m}}$ are presented; ${ }^{1}$ no LWR found for Brazil, ${ }^{2} \mathrm{LWR}$ not found for NE Brazil; ${ }^{3}$ new species name according to Tavera et al. (2011) and Marceniuk et al. (2016), ${ }^{4} \mathrm{TL}_{\text {max }}$ obtained in this study higher than currently reported in FishBase, ${ }^{5} b$ statistically different from 3 .

All results for $b$ from the LWR are within the usual range (2.5-3.5) described by Carlander (1969). Species for which only juveniles were sampled were excluded from this analysis as small individuals change during growth (Lima Filho et al. 2006), resulting in very different $b$ values. These values may also be influenced by differences among seasons (Pauly 2010), localities, and feeding habits (Wootton 1998). This is the first time that an LWR is presented for G. cavifrons, and $P$. crenulatus under their revised scientific names (Tavera et al. 2011, Marceniuk et al. 2016).

\section{ACKNOWLEDGEMENTS}

This study was supported by Fundação de Apoio à Pesquisa e Extensão de Sergipe (FAPESE) and Projeto de Monitoramento do Desembarque Pesqueiro (PMPDP) VI \& VII (Grant numbers 2600.0094374.14.4 and 2600.0099827.15.4). T.M.R.R. Barreto and J.J.C. Reis Jr. thank FAPESE/PMPDP for their scholarships. All authors are deeply grateful to Mrs Maria Morais and artisanal fishers from Pirambu for the collection of all samples used in this study, to Ana Cláudia Gaspar dos Santos for helping with sample processing, and to Robson Rosa for providing the map of the study area.

\section{REFERENCES}

Branco J.O. 2005. Biologia e pesca do camarão setebarbas, Xiphopenaeus kroyeri (Heller) (Crustacea, Penaeidae), na Armação do Itapocoroy, Penha, Santa Catarina, Brasil. [Biology and fishery of Atlantic seabob-shrimp Xiphopenaeus kroyeri (Heller) (Crustacea, Penaeidae), at Armação do Itapocoroy, Penha, Santa Catarina, Brazil.] Revista Brasileira de Zoologia 22 (4): 1050-1062. [In Portuguese.] DOI: 10.1590/ S0101-81752005000400034

Carlander K.D. 1969. Handbook of freshwater fishery biology. Iowa State University Press, Ames, IA, USA.

Carpenter K.E. 2002. The living marine resources of the western central Atlantic. Volume 3: Bony fishes part 2 (Opistognathidae to Molidae), sea turtles and marine mammals. FAO Species Identification Guide for Fishery Purposes and American Society of Ichthyologists and Herpetologists Special Publication No. 5. FAO, Rome.

Freire K.M.F., Araújo, A.R.R. 2016. Analysis of marine catch off the state of Sergipe (1950-2010). Arquivos de Ciências do Mar 49 (1): 13-29. 
Freire K.M.F., Rocha G.R.A., Souza I.L. 2009. Lengthweight relationships for fishes caught by shrimp trawl in southern Bahia, Brazil. Journal of Applied Ichthyology 25 (3): 356-357. DOI: 10.1111/j.14390426.2009.01220.x

Froese R. 2006. Cube law, condition factor and weightlength relationships: History, meta-analysis and recommendations. Journal of Applied Ichthyology 22 (4): 241-253. DOI: $10.1111 / \mathrm{j} .1439-0426.2006 .00805 . x$

Froese R., Pauly D. (eds.) 2018. FishBase. [Version 06/2018] www.fishbase.org

Hilborn R., Walters C.J. 1992. Quantitative fisheries stock assessment: Choice, dynamics and uncertainty. Chapman and Hall, New York, NY, USA. DOI: 10.1007/978-1-4615-3598-0

Lima Filho J.M., Lessa R., Stosic B., Duarte Neto P.J., Vieira J.W. 2006. Morphological discrimination in juveniles of two Selene species (Teleostei: Carangidae) using truss net distances. Brazilian Archives of Biology and Technology 49 (2): 321-238. DOI: 10.1590/ S1516-89132006000300008

Macieira R.M., Joyeux J.-C. 2009. Length-weight relationships for rockpool fishes in Brazil. Journal of Applied Ichthyology 25 (3): 358-359. DOI: 10.1111/j.1439-0426.2008.01118.x

Marceniuk A.P., Caires R., Siccha-Ramirez R., Oliveira C. 2016. Review of the harvestfishes, genus Peprilus (Perciformes: Stromateidae), of the Atlantic coast of South America. Zootaxa 4098 (2): 311-332. DOI: 10.11646/zootaxa.4098.2.6

Nelson J.S., Grande T.C., Wilson M.V.H. 2016. Fishes of the world. 5th edn. John Wiley and Sons, Hoboken NJ, USA.
Pauly D. 2010. Gasping fish and panting squids: Oxygen, temperature and the growth of water-breathing animals. Excellence in ecology, Book 22. International Ecology Institute, Oldendorf/Luhe, Germany.

Santos M.C.F. 1996. Participação da flora e fauna acompanhantes da pesca de camarões em Tamandaré (PE) e foz do Rio São Francisco (AL/SE). [Participation of flora and fauna by-catch of shrimp fisheries in Tamandaré (PE) and São Francisco River Mouth (AL/SE.] Trabalhos Oceanográficos da Universidade Federal de Pernambuco 24 (1): 197-210. [In Portuguese.] DOI: 10.5914/tropocean.v24i1.2707

Stergiou K.I., Tsikliras A.C. 2006. Scientific impact of FishBase: A citation analysis. Fisheries Centre Research Reports 14 (4): 2-6.

Tavera J.J., Pizarro A.A., De la Cruz-Agüero J., Balart E.F. 2011. Phylogeny and reclassification of the species of two neotropical grunt genera, Anisotremus and Genyatremus (Perciformes: Haemulidae), based on morphological evidence. Journal of Zoological Systematics and Evolutionary Research 49 (4): 315 323. DOI: 10.1111/j.1439-0469.2011.00622.x

Tischer M., Santos M.C.F. 2001. Algumas considerações sobre a ictiofauna acompanhante da pesca de camarões na foz do rio São Francisco (Alagoas/Sergipe - Brasil). [Some comments on the bycatch of shrimp fisheries in the São Francisco River Mouth (Alagoas/Sergipe - Brazil).] Boletim Técnico-Científico do CEPENE 9 (1): 155-165. [In Portuguese.]

Wootton R.J. 1998. Ecology of teleost fishes. Kluwer Academic Publishers, Dordrecht, the Netherlands.

Received: 31 October 2017

Accepted: 24 May 2018

Published electronically: 30 September 2018 